\title{
Telefonisch spreekuur
}

\section{Maakt COVID-19 een einde aan koudwatervrees over nieuwe werkwijzen?}

\author{
Diederik Wieman, Martijn Haentjens, Katrien Mortelmans en Bas Sorgdrager
}

De komst van COVID-19 leidde tot een tijdelijke stop van het fysieke spreekuur. Nu het ergste voorlopig achter de rug lijkt, worden de spreekuren weer langzaam opgestart. Maar uit een rondgang langs bedrijfs- en verzekeringsartsen blijkt dat zij mogelijkheden zien hun werkwijze blijvend aan te passen: je hoeft mensen niet voor alles op te roepen. De beroepsverenigingen van bedrijfs- en verzekeringsartsen adviseerden vanwege de COVID-19 pandemie geen een-op-een-spreekuurcontacten uit te voeren. Dit betekende dat beoordeling en begeleiding in de afgelopen maanden vooral met behulp van telefonische spreekuren plaatsvond. TBV vroeg vijf Nederlandse en Belgische collega's hoe dit voor hen was. Wat zijn de voor- en nadelen? Hoe beïnvloedt het je oordeel of je begeleiding? Wat vinden klanten ervan?

\section{Bedrijfsarts Geert Koster:}

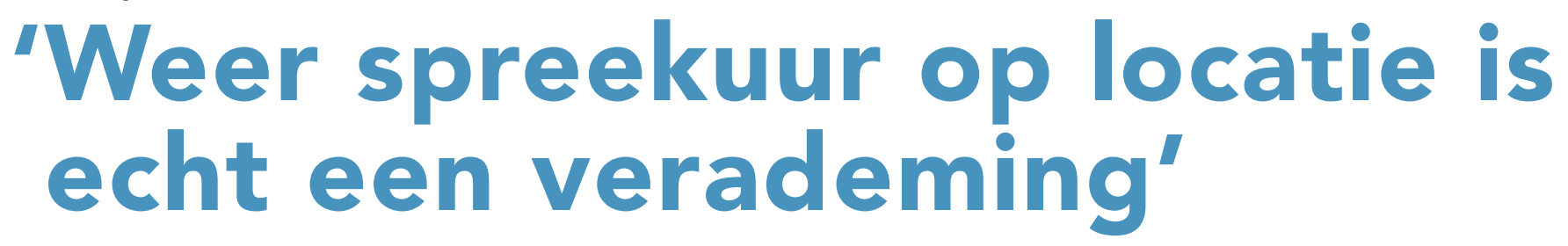

Geert Koster is bedrijfsarts en levert met zijn Quintus Five Group flexibel gezondheidsmanagement aan kleine en grote bedrijven.

Hoe is het telefonisch consulteren bevallen? Het was ongelofelijk wennen in het begin. We zijn gewend aan interactie met mensen en mensen te zien. Dat mis je met telefonische consulten. Ik had moeite om voldoende tijd en ruimte bij mijzelf te vinden om de consulten per telefoon te doen. Gaandeweg ging dat beter. Zeker toen ik eenmaal een goed beveiligde vorm van videobellen had gevonden. Dat bevalt beter dan alleen telefoneren.

Waar liep je tegenaan?

Ik praat sowieso liever face-to-face, ook privé in onderling contact met vrienden. Ik moest mij dan ook over een bepaalde schroom heen zetten. Wat hielp is dat ik niet meer met de telefoon aan mijn oor zat, maar een headset ging gebruiken. Je kunt daardoor meeschrijven en je zit er ook wat gemakkelijker bij. Verder merkte ik dat het bijzonder lastig is om mensen met fysieke klachten te beoordelen. Bij rugklachten bijvoorbeeld, ben je toch snel geneigd om even die rug zelf te bekijken op een consult. Dat mis je. Ook bij psychische klachten mis je de interactie met mensen. Juist daarbij is het belangrijk dat je ook de non-verbale signalen meekrijgt.

Blijf je ook na corona telefonische consulten houden? Gaandeweg ging het beter en nu, na een aantal weken, begin ik ook de voordelen te ervaren om bepaalde consulten telefonisch te blijven doen. Bijvoorbeeld omdat het reistijd scheelt voor mijzelf of klanten. Ook kan ik op deze manier

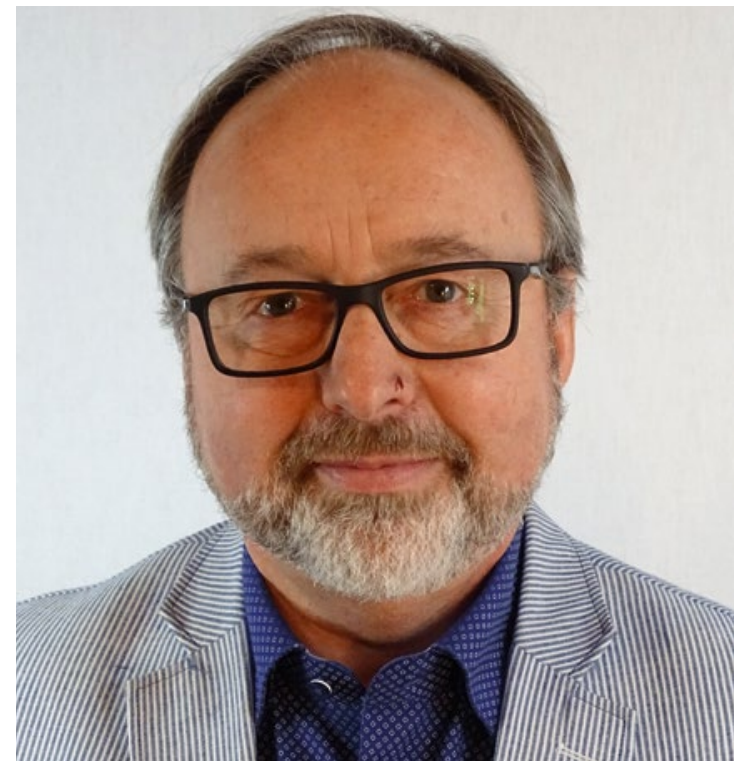

klanten die verder weg zitten toch dienstverlening bieden. Wel merk ik dat het vermoeiender is. Dat hangt samen met het feit dat je kijken en luisteren niet kunt combineren. Je mist de non-verbale signalen dus ga je extra inspannen om te luisteren. Je moet er meer effort in steken om eruit te halen wat je wilt.

Kun je de belastbaarheid goed beoordelen door de telefoon?

Daar heb ik mijn twijfels over. Bij fysieke klachten heb je controlevragen, bij psychische aandoeningen is dat veel lastiger. Ik heb het idee dat in een telefonisch consult mensen 
je echt willen overtuigen van hun aandoening en dan de neiging hebben om te overdrijven. Je moet daar toch je weg in vinden, maar ook daar ontwikkel je na enige tijd wat routine in. En het is makkelijker als je mensen kent, is mijn ervaring. Als een eerste consult alleen telefonisch gaat heb je geen beeld bij de mens en moet je alleen afgaan op de stem en de intonatie. Dan heb ik grote vraagtekens of wij de belastbaarheid goed vaststellen.

Ben je toeschietelijker als je telefonisch werkt? Vertrouwen in de mensen moet het uitgangspunt van ons werk zijn. Maar het gaat wel een belangrijkere rol spelen in je beoordeling. Als ik tegenover iemand zit, kijk je ook naar de houding en hoe ze reageren. Bij een videoconsult is het een voordeel dat je ook een kijkje bij de mensen thuis krijgt. Dat kan belangrijk zijn. Ik had een man die zich heel netjes presenteerde maar tijdens videobellen zag ik dat het thuis een enorme rommel was. Er is dan een discrepantie tussen hoe iemand zich presenteert en hoe die thuis leeft. Dat kan van belang zijn bij je beoordeling.

Wat vinden de klanten er zelf van? Daar moet ik een verschil maken tussen telefoneren en beeldbellen. Dat eerste vinden mensen over het algemeen prima. Zeker wanneer je het even uitlegt dat dit vanwege corona moet. Maar ik merk dat een aantal mensen geen videoconsulten wil. Dat kan zijn omdat ze niet willen dat je bij ze binnenkijkt, je geeft dan toch iets van je privacy op. Ik probeer wel uit te leggen dat het mijn werk gemakkelijker maakt als ik ook iets kan zien. Ik doe ook niet zomaar een videoconsult, er gaat meestal een telefoontje aan vooraf waarin ik uitleg waarom ik dat wil. Maar uiteindelijk laat ik ze wel de keus. Net zoals mensen kunnen aangeven dat ze het onprettig vinden als ik op huisbezoek kom.

De opdrachtgevers snakken ernaar dat je weer komt. Ik doe heel veel spreekuren op locatie. Ze missen de bedrijfsarts, waarbij vooral de interactie met leidinggevenden heel belangrijk is. Ik heb veel klanten in de industrie en die vinden het belangrijk dat de bedrijfsarts op de werkvloer is. Bij sommige klanten werk ik al vifttien tot twintig jaar, daar ben ik echt onderdeel van het bedrijf. Ik heb het hier en daar weer opgestart en dat is echt een verademing.

Is dit nu het nieuwe normaal of gaan we terug naar de oude situatie?

Ja, ik denk dat het blijft. Ik heb een nieuwe klant die wat verder weg zit, daar spreek ik mee af dat ik niet elke keer drie uur in de auto stap. Dat is onpraktisch en kost veel geld. Het bedrijf heeft behoefte aan een bedrijfsarts die snel inzetbaar is, en dat kan prima met videoconsulten. Voor iedereen geldt dat corona heeft laten zien dat je een aantal dingen prima kunt doen op andere plekken dan je traditionele werkplek. Dat blijft. Maar het kan nooit een vervanging zijn voor het normale werk wat wij doen.

\section{Bedrijfsarts Suzanne Driessen:}

\section{"Ik wil mensen zien, daarom heb ik dit vak gekozen"}

Suzanne Driessen is pas afgestudeerd bedrijfsarts en werkt in die functie voor arbodienstverlener Healthcare Corporate in Venlo.

Hoe is het telefonisch consulteren bevallen? Het was heel erg wennen in het begin. Vooral de eerste weken merkte ik dat ik tijd overhield. Het scheelt mij dagelijks twee uur reistijd omdat ik van Maastricht naar Venlo moet rijden. In twee uur kun je best veel doen qua sport of huishouden. Dus om die reden is het fijn, maar vakinhoudelijk was ik minder blij. Het contact met mensen miste ik enorm. Ik ben echt wel een mensenmens dus ik wil ze ook echt graag zien. Als je telefonisch spreekuur houdt mis je zoveel non-verbale signalen. Voorheen hield ik sporadisch telefonisch spreekuur, eigenlijk alleen als iemand niet in staat was om op spreekuur te komen.

Waar liep je tegenaan?

Je wilt de belastbaarheid van mensen bepalen. En dat is iets wat telefonisch gewoon minder goed lukt. Vaak is het ook al belangrijk om te zien hoe iemand van de wachtkamer naar je spreekkamer loopt. En je kunt geen lichamelijk onderzoek doen. Dat mis je ook. Het is gewoon lastig om een goed beeld te vormen. Natuurlijk vraag je door, maar bij een enkeling vond ik het toch nodig om een huisbezoek te regelen.

Ik heb ook wel gevraagd of mensen een foto wilden toesturen van hun gipsen been. Dat geeft toch een beetje een beeld, en dat helpt wel. Maar overleg met werkgever en werknemer over wat nog wel mogelijk is, blijft lastig.

In welke situaties kun je geen oordeel geven? Bij het opstellen van de FML wil ik iemand zien. Bij een eerste contact ook, net als bij burn-out of andere psychische klachten. Dan wil je toch iemand in de ogen kijken. En eigenlijk wil ik bij fysieke klachten ook zelf lichamelijk onderzoek kunnen doen als dat nodig is. 
Blijf je na corona telefonisch consulten houden? We zijn langzaamaan weer begonnen met fysieke spreekuren. De artsen bij ons komen allemaal een dag in de week naar kantoor, zodat we elkaar niet kruisen. Het zal nog wel even duren voor alles weer bij het oude is. Ik heb net mijn diploma gehaald als bedrijfsarts en wat ik daar nu mee doe is een beetje bellen en met mensen praten. Ik merkte vorige maand dat ik er best wel doorheen zat. Ik wil nu toch echt mensen zien, want daarom koos ik dit vak. Telefonisch spreekuur geeft echt een minder goed gevoel. Bij mensen die ik al een keer zag kun je er misschien mee uit de voeten, maar bij ongeveer de helft vond ik het niet toereikend. Je pluis-niet-pluisgevoel is minder. Je hebt medisch inhoudelijk onvoldoende grip en komt er moeilijker achter waarom een proces stagneert of waarom iemand niet aan het werk wil. Voor de werk-privébalans is het denk ik wel goed om een dag per week telefonisch consult te blijven doen. Maar voor de beoordeling geef ik daar niet de voorkeur aan.

Kun je op basis van telefonisch contact een volwaardige probleemanalyse maken?

Dan schiet je telefonisch toch wel tekort.

Ben je toeschietelijker als je telefonisch werkt? Ik denk dat ik inderdaad wat softer ben bij een telefonisch consult dan wanneer ik de mensen zie. Je gunt iemand denk ik net wat eerder het voordeel van de twijfel, je gaat als arts wat aan de zekere kant zitten.

Wat vinden de klanten er zelf van? Dat wisselde. Meestal was er begrip, maar ik had ook een man met psychische klachten die het raar vond om alles met mij te delen: 'ik ken jou niet en heb je nog nooit gezien'. Een ander was wat argwanend en vroeg 'met wie bel ik nu eigenlijk?' Psychologen en fysiotherapeuten schalen ook weer langzaam op, mensen vragen ze zich af waarom het bij ons niet het geval is.

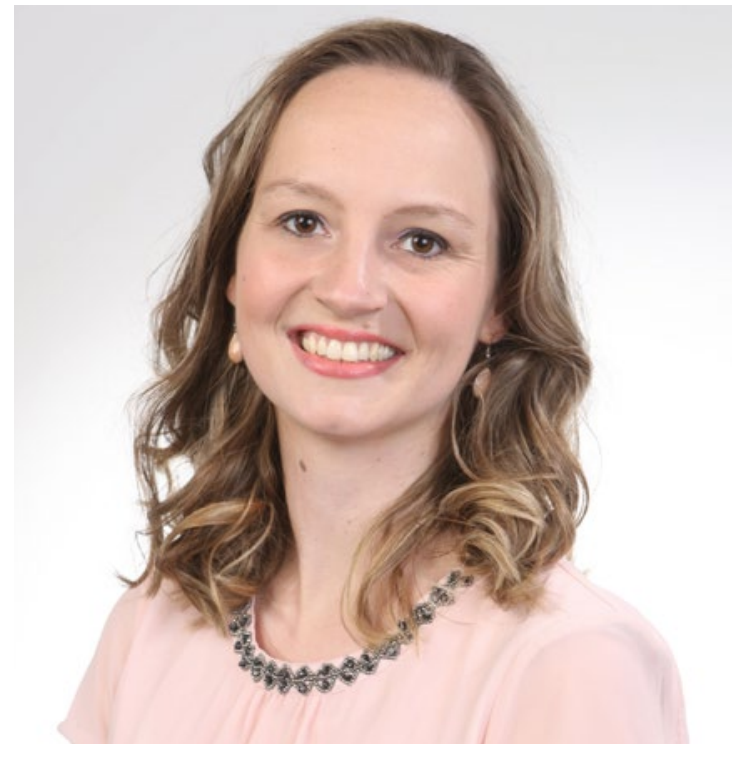

Hoe ben je gesteund en gefaciliteerd?

Ik werkte gewoon van huis op mijn eigen laptop. Er was geen beeldbelfaciliteit. We hebben dat wel uitgeprobeerd, maar het was te omslachtig, onder meer omdat de casemanagers dan telkens een kwartier van tevoren linkjes moesten sturen.

Is dit nu het nieuwe normaal of gaan we terug naar de oude situatie?

Neem het zekere voor het onzekere en denk goed na voor je fysiek spreekuur doet. Ik doe alleen fysieke spreekuren als het raam open kan, we mondkapjes hebben en er desinfectans aanwezig is. En we hebben nu ook een spatscherm tussen ons en de cliënt. Dat zijn wellicht veel maatregelen, maar je wilt veiligheid voor jezelf en je cliënt. Verder heb ik over mijzelf geleerd dat ik meer een mensenmens ben dan ik dacht. Als er een tweede golf komt en we zijn weer aan huis gekluisterd, dan moeten we toch eerder kijken of we kunnen beeldbellen of op een andere manier fysiek contact kunnen hebben met onze cliënten.

\section{Aios verzekeringsgeneeskunde Willem Methorst: "Elke onzorgvuldigheid uitsluiten vanwege risico"s"}

\begin{abstract}
Willem Methorst werkt bij UWV in Den Bosch en is in de afrondende fase van zijn opleiding tot verzekeringsarts. Hij werkt nu vijf jaar bij UWV waar hij met name WIA- en RIV-beoordelingen doet, maar ook deskundigenoordelen.
\end{abstract}

Hoe is het telefonisch consulteren bevallen?

Wisselend. Het was voor corona ook al zo dat wij lang niet iedereen op het spreekuur zagen. De laatste twee jaren probeerden we al proportioneler te werken, simpelweg omdat we capaciteitsproblemen hebben. We waren dus al gewend om te bellen voor een korte indruk of om te weten welke behandelingen er lopen. In de eerste fase van de crisis ga je het doen, gewoon omdat het moet. Maar gaandeweg kreeg ik meer bezwaren tegen telefonische spreekuren en zag ik ook meer de gevaren en de risico's. 


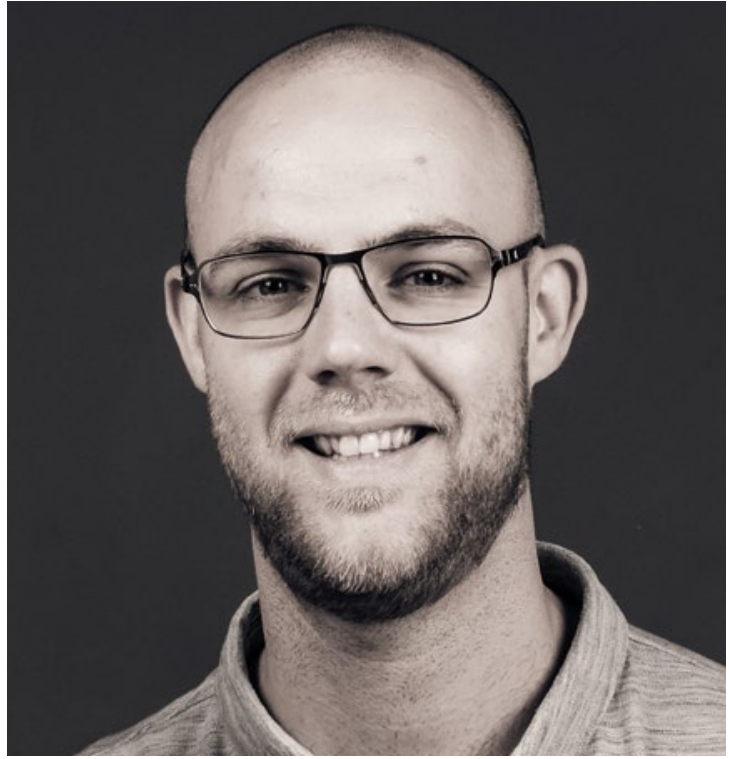

Waar liep je tegenaan?

Je hebt toch een ander contact omdat je iemand niet in de ogen kijkt, niet aanraakt, geen hand geeft. Je kunt ook moeilijker spanning bij mensen weghalen. We zijn toch het gezicht van UWV, een instituut waar mensen afhankelijk van zijn. Er leven allerlei sentimenten of angsten bij mensen als ze een beoordeling tegemoet gaan. En dan moet je via de telefoon toch het ijs zien te breken en iemand op z'n gemak stellen. Ik heb het idee dat dat niet elke keer even goed lukte. Voor mijzelf merkte ik ook dat het inspannender was. Als je non-verbale informatie mist, ga je meer doorvragen om duidelijkheid te krijgen. Dat maakt het ook vermoeiender. Je hebt je vaste route binnen je gesprek, maar ik heb het idee dat ik toch af en toe informatie miste. Ik ben in opleiding dus ik word gesuperviseerd en dan kreeg ik achteraf toch opmerkingen van: 'Heb je hier of daar aan gedacht?' Ook had ik soms de indruk dat ik toch niet het hele verhaal hoorde. Of je een niet-pluisgevoel aan een gesprek overhoudt. Bij een klant ging het over fysieke klachten, maar ze klonk vlak aan de telefoon. Ik had willen zien hoe ze erbij zat. Ik heb later nog in het dossier gekeken of er iets over mentale problematiek te vinden was en het ook met mijn supervisor overlegd. Uiteindelijk heb ik het afgerond, maar wel in mijn overwegingen opgeschreven dat ik vanwege de aard van het contact niet kon uitsluiten dat ook psychologische factoren een rol spelen. Ook merk ik dat ik meer medische informatie opvraag bij behandelaren. In het begin vond ik dat heel lastig, omdat je het verzoek kreeg om daar zuinig mee te zijn. Dat is anders nu. Door de andere manier van werken gaat er toch sneller een bericht of verzoek richting huisarts, specialist of fysiotherapeut.

In welke situaties kun je geen oordeel geven? Als iemand zich met lichamelijke klachten presenteert wil je toch zelf onderzoek doen. In sommige gevallen heb ik het wel af kunnen ronden omdat er uitgebreide informatie lag van een specialist, bedrijfsarts of een fysiotherapeut die de bewegingsmogelijkheden formuleert. Bij psychische problematiek kom je met anamnestische informatie een heel eind, maar je krijgt geen algemene indruk. Hoe zit iemand erbij? Kijkt iemand weg bij bepaalde vragen? Je mist allerlei signalen die aanleiding geven om wel of juist niet door te vragen. Ik geef ook geen oordeel wanneer er eerdere beoordelingen zijn die elkaar tegenspreken. Of wanneer de klant het niet eens is geweest met een beoordeling of wanneer er risico is op een tuchtklacht. Die gevallen stelde ik uit tot we weer mensen mochten zien. Elke onzorgvuldigheid wilde ik uitsluiten want dat levert risico's op.

Blijf je ook na corona telefonische consulten houden? Ik denk dat ik als aios verzekeringsgeneeskunde misschien wat meer geneigd ben om hier mee door te gaan dan mijn oudere collega's. Maar in het algemeen is er wel wat koudwatervrees weggehaald. Iedereen heeft kennis kunnen maken met de voor- en nadelen van telefonisch spreekuur of beeldbellen. Qua tijd heeft het wat mij betreft niet veel voordelen, dus daarom zal ik voor een volledige beoordeling altijd terugvallen op het fysieke spreekuur. Uitzondering daarop zijn de evidente gevallen. Bijvoorbeeld wanneer de bedrijfsarts uitgebreid heeft beargumenteerd, de klant het er mee eens is en alles ook nog eens wordt ondersteund door gegevens uit de behandelende sector. Ga ik dan nog tot een ander oordeel komen? Nee, hoogstwaarschijnlijk niet.

\section{Kun je op basis van telefonisch contact een} volwaardige probleemanalyse maken?

Je denkt dat je een volledig beeld hebt, terwijl je op sommige punten had doorgevraagd als iemand tegenover je had gezeten. Bij een deskundigenoordeel is ook bepalend hoe de relatie met de werkgever is en de samenwerking met collega's. Wanneer iemand dan meteen met z'n ogen begint te rollen als ik daarover vraag, wil ik dat wel graag signaleren. Daarom denk ik dat je echt iemand moet zien om een volledig beeld te krijgen.

Ben je toeschietelijker als je telefonisch werkt? Een lastige vraag. Misschien in de claimklacht zelf. Je wilt een case pragmatisch afronden en als het arbeidsdeskundig niet veel consequenties heeft, bijvoorbeeld omdat de uitkomst niet heel erg gaat veranderen, ben je misschien wat toeschietelijker. Omgekeerd kan het ook zijn dat je beperkingen helemaal mist omdat mensen zelfs op een vragenlijst niet alles vermelden waar ze echt last van hebben. Als je tegenover iemand zit, zie je hoe ze bewegen, of dat ze ergens een oud litteken hebben. Soms hebben ze een heupprobleem of een arm die niet volledig strekt, maar melden ze dat niet omdat ze daar prima mee hebben leren leven. Maar het is wel een beperking.

\section{Wat vinden de klanten er zelf van?}

In het begin van de crisis kon ik zeggen: 'het mag niet' en daar was dan veel begrip voor. Nu we beperkt spreekuur 
doen, ligt het wat anders. Iedereen denkt dan: waarom mag ik niet komen of waarom moet ik juist wel verschijnen? Dat is wat lastiger uit te leggen. Ik ben benieuwd of het begrip blijft.

Hoe ben je gesteund en gefaciliteerd?

Inmiddels is het uitgerold, maar wij hadden geen mogelijkheid om te beeldbellen, terwijl dat in andere segmenten al normaal was of het heel snel werd opgestart. Ook zijn er elders al eerder weer fysieke spreekuren gestart. Dus $i k$ vind dat we daarmee tijd hebben verloren. Ik voelde me niet gesteund vanuit het centrale beleid. Vooral door het signaal vanuit het crisisplan om zoveel mogelijk beoordelingen telefonisch af te ronden en je richting de adviseur verzekeringsarts te verantwoorden wanneer je een beoordeling uitstelde. Dat legde een druk bij de artsen om afbreuk te doen aan de kwaliteit van de beoordelingen. Gelukkig hadden onze adviseurs, op ons kantoor, ook kritiek op dit crisisplan en voeren we onze eigen koers.

Is dit nu het nieuwe normaal of gaan we terug naar de oude situatie?

Ik vind niet dat je voor alles een spreekuur nodig hebt, maar je moet de keuze wel aan de professionals overlaten en niet aan de beleidsmakers. We moeten met de artsengroep kijken hoe we de kwaliteit hoog houden als we andere methoden gebruiken. Wanneer doe je dat wel en niet? Wat vinden we ervan? Dat zijn zaken die in onderlinge toetsing of aan de hand van casuïstiek besproken moeten worden.

\section{Verzekeringsarts en opleider Els van der Molen:}

\section{'Minder verbaalkrachtigen doe je te kort"}

Els van der Molen werkt al een kleine twintig jaar bij UWV Nijmegen. Daar is ze momenteel drie dagen per week actief als verzekeringsarts, met name claimbeoordeling en deskundigenoordeel. De andere twee dagen werkt Els als instituutsopleider bij SGBO.

Hoe is het telefonisch consulteren bevallen? Het staat mij nog precies bij. Half maart. Ik kreeg een stapel dossiers op mijn bureau en ik moest maar eens gaan kijken welke cliënten ik kon bellen en welke ik moest uitstellen. Er heerste ook een beetje een sfeer van hoe kan dat nou? Iemand beoordelen zonder hem of haar te zien? Je ziet de uitdrukking niet, er is geen wisselwerking, je mist heel veel. En ook ik dacht: je kunt die psychische beperkingen nooit helemaal goed inschatten. Maar gaandeweg vond ik het verrassend dat je toch een redelijk beeld krijgt, ook al heb je iemand alleen maar aan de telefoon. Wat wel belangrijk is dat dat de cliënten wisten dat ze door mij gebeld zouden gaan worden. Je geeft ze dan tijd om zich voor te bereiden zodat ze hun klachten goed naar voren kunnen brengen.

Waar liep je tegenaan?

Ik merkte dat het meer moeite en kracht kost en het langer duurt. Je moet vaak meerdere malen uitleggen wat de bedoeling is van het spreekuur en ook de afsluiting waarin je uitlegt wat het resultaat van het gesprek is, vraagt meer tijd. Het was redelijk goed te doen om de belastbaarheid vast te stellen, maar de uitleg van procedures en uitkomsten vond ik lastiger.

In welke situaties kun je geen oordeel geven?

Ik ervaar zelf dat het lastig is wanneer je lijnrecht tegenover

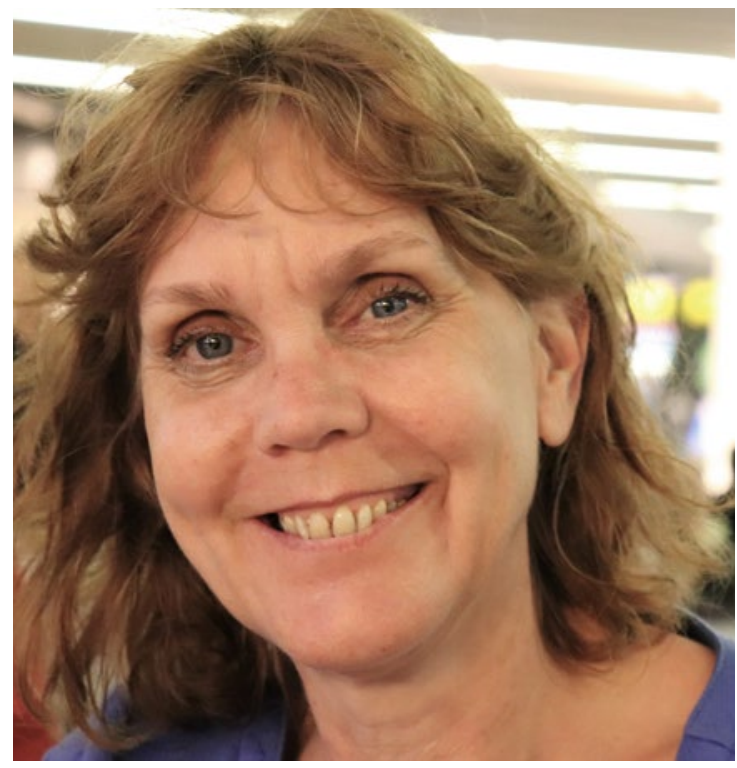

de mening van de cliënt staat. Ik had bijvoorbeeld een hoog opgeleide cliënt waarvan ik vond dat werkhervatting aan de orde was. Maar de cliënt was het daar helemaal niet mee eens. Je hebt dan twee totaal verschillende meningen over de belastbaarheid. Tijdens een spreekuur zie je ook hoe iemand eruit ziet en reageert, de blik in de ogen. Het is anders, je krijgt meer informatie. Die extra zekerheid miste ik in het telefoongesprek waardoor ik mijn beslissing niet door durfde te zetten. Ik heb daarom voorgesteld om de persoon zodra het kan voor een fysiek spreekuur uit te nodigen. Mijn gevoel zegt ook dat het voor de cliënt zelf beter te verteren is, wanneer je een-op-een vertelt dat de belastbaarheid anders uitvalt dan gedacht. 
Hoe was het dat je geen lichamelijk onderzoek kon doen?

Je kunt terugvallen op de medische informatie van de dokters die de cliënt wel lichamelijk hebben onderzocht. Nu heb je nog het geluk dat je een eerdere beoordeling hebt of een uitgebreid verslag van de bedrijfsarts, huisarts of specialist. Daar kun je nu nog voldoende informatie uit halen, maar als de coronamaatregel langer geduurd zou hebben en niemand nog cliënten ziet, dan veroudert de informatie. Dan word je onzeker en wordt een oordeel geven moeilijker.

Kun je een volwaardige probleemanalyse maken via een telefonisch consult?

Volwaardig klinkt zo perfect, maar ik denk dat het in de meeste gevallen wel voldoende is omdat ik natuurlijk al heel veel informatie heb. Ik denk daarom dat ik niet veel onrecht aanricht met telefonische consulten.

Ben je toeschietelijker als je telefonisch werkt? Ik heb aan mijn adviserend verzekeringsarts gevraagd hoe de verdeling 80-100, 35-80 en minder dan 35 is. Voor mijn gevoel heb ik meer 80-100 gegeven, maar de cijfers wijzen uit dat de verdeling niet anders is dan normaal. Dus misschien is het meer een gevoel dat ik aan de telefoon wat toeschietelijker ben.

Wat vinden de cliënten ervan?

Meestal waren de cliënten wel akkoord met een telefonisch spreekuur. Ze vonden dat prima. Soms zat er een zoon of dochter bij, wat ook prettig is. Niet iedereen begrijpt meteen even snel wat er boven hun hoofd hangt, en met een zoon of dochter erbij is dat dan toch wat makkelijker. De meeste mensen bedankten voor het gesprek en volgens mij hebben ze ook het gevoel gehoord te zijn.

Hoe ben je gesteund door je werkgever We kregen centraal berichten waarin stond wat we wel en niet moesten doen. Dat was wel een soort van cultuurshock. Met name dat we cliënten - als dat nodig was - maar het voordeel van de twijfel moesten geven, leverde weerstand op bij mij en mijn collega's. Uitein- delijk hebben we de werkwijze van centraal wat naast ons neergelegd en zijn we onze eigen weg gegaan. Je vertrouwt op je professionaliteit en je hebt je professionele autonomie. Uiteindelijk doe ik de beoordeling en moet ik deze voor mijzelf kunnen verantwoorden.

Blijf je ook na corona telefonische consulten houden? Ik zal heel blij zijn wanneer ik weer gewoon aan het werk kan en geen telefonisch spreekuur meer hoef te doen. De enigen die ik normaal gesproken bel, zijn de verkorte wachttijd WIA-gevallen. En daar blijft het bij. De traditionele werkwijze kost mij minder energie. Ik vind het ook fijner om informatie te krijgen van iemand die tegenover mij zit. Dat ik kan zien hoe deze kijkt en reageert. Ik vind het fijn om mensen op te halen uit de spreekkamer en kijken hoe ze lopen. Het geeft allemaal informatie. Live is dat anders dan via bellen of beeldbellen. Dat is toch tweedimensionaler. De mensen die heel fel en claimend zijn, vormen niet het grootste probleem, die maken ook aan de telefoon wel duidelijk wat ze denken of vinden. Ik maak mij meer zorgen om de mensen die hun problemen bagatelliseren. De minder verbaalkrachtigen doe je aan de telefoon te kort.

Is dit nu het nieuwe normaal of gaan we terug naar de oude situatie?

Ik denk en hoop echt dat het een tijdelijke zaak is. Voor de cliënt kan het voordelig zijn, met name voor mensen die vanuit een uithoek van ons district moeten komen. Voor hen is het heerlijk dat ze niet anderhalf uur hoeven te rijden. Voor mijzelf heeft het geen voordelen. Ik heb ook niet vanaf huis gewerkt. Je moet dan een goede werkplek hebben, want het is niet handig als je met een laptop in een stoel zit of aan de keukentafel. Bovendien vind ik het vervelend dat de scheiding tussen werk en privé vervaagt, dat je de deur niet uitkomt en geen collega's ziet. Ik miste ook de rit op de fiets naar kantoor. Telefonisch consulteren levert mij ook geen tijdwinst op. Het enige is dat je geen tijd kwijt bent aan lichamelijk onderzoek. Dat is winst, maar eigenlijk ook weer niet, want het is natuurlijk gewoon een nadeel dat je mensen niet kunt onderzoeken.

\section{Verzekeringsarts Johanna Buelens:}

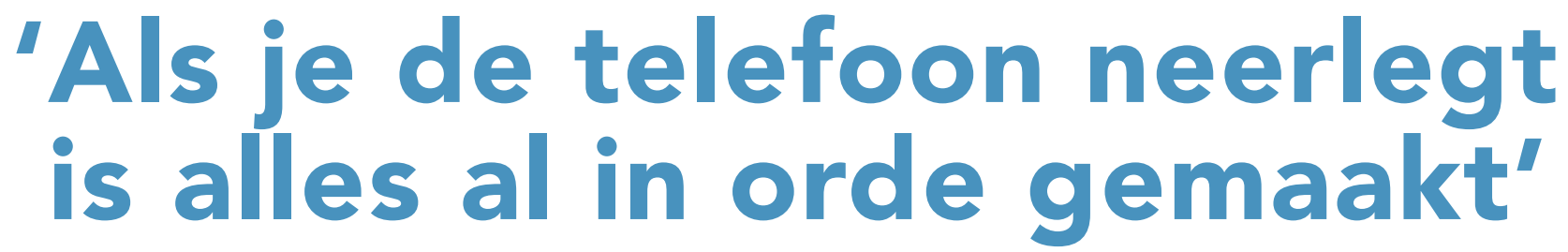

Johanna Buelens werkt als adviserend arts voor de Landsbond van de Neutrale Ziekenfondsen in België. Ze beoordeelt - doorgaans na drie ziektemaanden - de arbeidsongeschiktheid van werknemers, zelfstandigen en werklozen, die op basis daarvan in aanmerking kunnen komen voor een uitkering ter hoogte van $60 \%$ van het laatstverdiende loon.
Hoe is het telefonisch consulteren bevallen? Uitstekend! Vooral omdat het heel efficiënt is. Het klinkt misschien heel cru, maar je verliest geen tijd aan de deur met jassen uit- en aandoen en oogcontact tijdens het gesprek. Je moet mensen immers af en toe aankijken om 
te laten zien dat je ze hoort en begrijpt. Bij een telefonisch consult hoef je alleen vragen te stellen en te luisteren en kun je intussen het dossier vullen. Als je de telefoon neerlegt heb je eigenlijk alles al in orde gemaakt. Je maakt een inschatting van het probleem en hoe snel je iemand moet oproepen om ze fysiek te zien. Voor die tijd kun je ze nog instructie geven en extra tijd om aan te tonen dat ze arbeidsongeschikt zijn. Bijvoorbeeld door nog eens naar de huisarts of psychiater te gaan, een foto of MRI te laten maken.

\section{Waar liep je tegenaan?}

Geen klinisch onderzoek doen is natuurlijk een nadeel. Je moet aan de mensen vragen wat er aan scheelt. Je kunt niet goed lopen, wat moet ik me daar bij voorstellen? Angst, wat bedoelt u daarmee? Ze moeten hun verhaal eigenlijk als een soort film voor mijn ogen afspelen. Mensen worden daar redelijk creatief in heb ik gemerkt. Als ze moeilijk lopen zeggen ze bijvoorbeeld: 'net zoals Doctor House' (uit de gelijknamige televisieserie - red.). Je hebt ze natuurlijk niet onderzocht, maar als je uitlegt dat hun klachten ook geobjectiveerd moeten worden, zijn ze meestal wel bereid om bijvoorbeeld de uitslag van een MRI of een psychiatrisch verslag op te sturen.

Is het mogelijk om telefonisch de belastbaarheid of arbeidsongeschiktheid goed te beoordelen?

Ik vind van wel. Waar ik mee begin is te vertellen wie ik ben, waarvoor ik bel en wat ik al weet. Anders is het nogal raar wanneer je meteen vraagt: hoe is het met uw depressie? Mensen zijn vrij snel betrokken en zeggen wat er scheelt, door welke arts ze opgevolgd worden. Ik vraag ook altijd hoe mensen het zelf inschatten. Als iemand bijna geschoffeerd is omdat hij een ziekte-uitkering krijgt, dan weet je dat hij het werk zal hervatten zodra daartoe de kans is.

Zijn er gevallen waarin het niet lukt om de arbeidsongeschiktheid vast te stellen?

Ja, dan denk ik vooral aan de psychische toestandsbeelden. Het gaat meestal om mensen die je niet kent. Als je iemand aan de telefoon hoort en die komt niet gemotiveerd over of lusteloos, dan weet je dus niet goed of dat een toestandsbeeld is of gewoon zoals iemand is. Ook bij orthopedische klachten waarvan nog geen beeldvorming beschikbaar is, is het lastig. Je moet dan toch klinisch onderzoek doen om vast te stellen dat er een beperking is. Als er wel beeldvorming is geweest van een rug of schouder, dan hoef ik de persoon niet te zien. Als de CT of RX een paar dagen oud is, kun je ervan uitgaan dat de daarin geobjectiveerde letsels inderdaad tot een beperking leiden.

Blijf je ook na corona telefonische consulten houden?

Zeker, het is efficiënter zoals ik al zei. Je kunt instructies geven, maar ook sancties opleggen als mensen hun

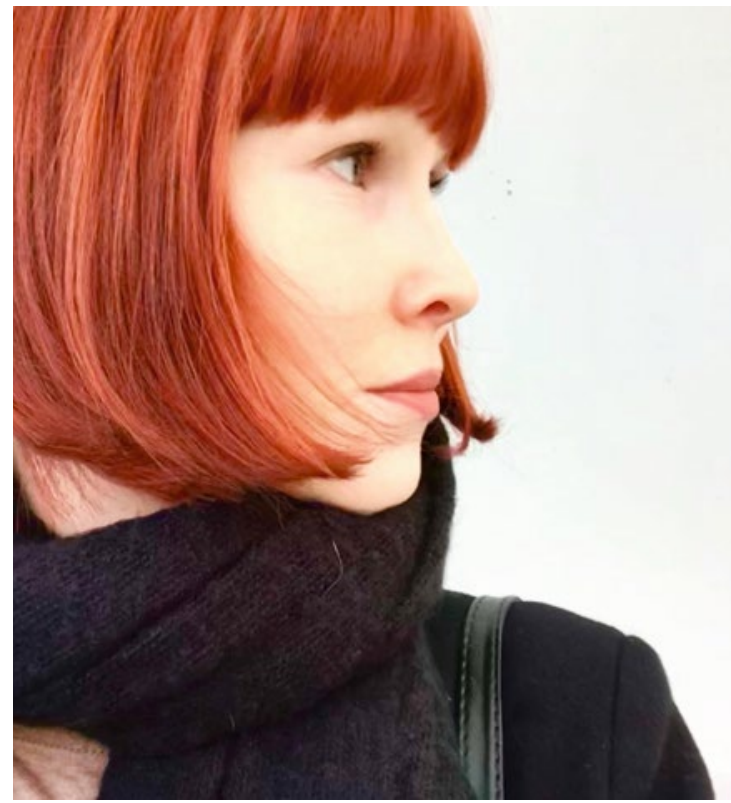

afspraken niet nakomen of wanneer ze zeggen iets op te sturen en het komt niet aan. Ook voor korte vragen, bijvoorbeeld hoe het gaat met mensen die ik doorverwezen heb naar beroepsherscholing (een opleiding betaald door de overheid om arbeidsongeschikten terug te leiden naar de arbeidsmarkt), laat ik mensen niet speciaal naar Antwerpen en of Hasselt komen. Of mensen die binnen een paar dagen het werk weer gaan hervatten. Als ze dat telefonisch melden laat je die ook niet meer komen.

Ben je toeschietelijker als je telefonisch werkt? Nee, de basis is om vertrouwen hebben in de mens. Ze kunnen je aan de telefoon misschien makkelijker om de tuin leiden, maar dat kunnen ze ook als ze tegenover je zitten. Vaak kun je het horen aan de manier waarop ze hun aandoening onderbouwen met voorbeelden uit het dagelijks leven. Als ze hun verhaal daarmee goed stofferen ben ik eerder geneigd het te geloven, maar het blijft altijd het woord van iemand. Of je ze nu alleen hoort of ook ziet. Het visuele aspect voegt dan niet veel meer toe. Als mensen minder arbeidsongeschikt zijn dan ze doen voorkomen, worden ze vaak defensief als ik doorvraag terwijl mensen die echt een beperking hebben dat heel goed kunnen uitleggen. Dan moet ik vaak zeggen: "Stop maar, ik snap het, $\mathrm{u}$ heeft het goed uitgelegd."

\section{Wat vinden de klanten er zelf van?}

De mensen zijn positief. Ze hoeven niet te reizen, geen parking te zoeken. Een aantal vindt het jammer dat ze niet in een echt consultatiegesprek kunnen toelichten wat ze overkomen is. Dat begrijp ik ook wel. Wel vinden nieuwe cliënten het soms lastig omdat zij mij niet kennen. Voor een eerste cliëntcontact is een fysieke afspraak handiger. 